\title{
The costs and efficacy of sediment mitigation measures for representative farm types across England and Wales
}

\author{
ADRIAN L. COLLINS ${ }^{1}$, YUSHENG ZHANG ${ }^{2}$ \& PAMELA NADEN ${ }^{3}$ \\ 1 Sustainable Soils and Grassland Systems Department, Rothamsted Research, North Wyke, Okehampton EX20 2SB, UK \\ adrian.collins@rothamsted.ac.uk \\ 2 ADAS, Pendeford House, Wobaston Road, Wolverhampton WV9 5AP, UK \\ 3 Centre for Ecology and Hydrology, Maclean Building, Crowmarsh Gifford, Wallingford OX10 8BB, UK
}

\begin{abstract}
A major collaborative research project in the UK is delivering new science to support improved targeting of on-farm pollution mitigation measures for the benefit of freshwater ecology. One important aspect of the project concerns a national scale evaluation of the costs and efficacy of packages of sediment mitigation measures which can be delivered over and above the existing implementation of abatement through various policy instruments including advice and new targeted agri-environment schemes. The assessment includes typical farm types present across England and Wales. Outputs from this assessment of costs and efficacy will eventually be used to help model the potential for closing the sediment pollution gap in those water bodies currently failing water quality targets due to sediment loss from agriculture. Some preliminary uncertainty ranges in costs $(-£ 146,402$ to $£ 175,631)$ and effectiveness $(0-80 \%)$ associated with a potential policy scenario implementing a large number (up to 93) of abatement measures at $95 \%$ uptake are presented in this paper.
\end{abstract}

Key words sediment; mitigation; costs; efficacy; farm scale; policy support

\section{INTRODUCTION}

Agricultural diffuse sediment pollution in England and Wales has been recognised as one of the key problems requiring improved abatement to help meet environmental targets for freshwater habitats (Collins et al., 2011). In particular, enhanced loadings of fine-grained sediment $(<63 \mu \mathrm{m})$ are associated with a number of important environmental issues receiving increasing attention from policy teams and catchment managers. Fine-grained sediment mobilisation and delivery through catchment systems exerts an important control on the transport and fate of nutrients and contaminants including, amongst others, phosphorus, heavy or trace metals, dioxins, polychlorinated biphenyls, radionuclides and pathogens (Horowitz et al., 1995; Warren et al., 2003; Kay et al., 2005; Ballantine et al., 2009). Sediment transport (coarse and fine) exerts a fundamental control on the hydro-geomorphological function and health of river systems and excessive fine sediment inputs can result in a range of detrimental impacts on aquatic ecology. High suspended sediment concentrations can, for example, impact on the behaviour and health of fish by reducing capacity to predate and damaging fish gills (Kemp et al., 2011). Increased sediment deposition and retention on the river substrate can degrade habitat quality by reducing permeability and porosity and attenuating hyporheic exchanges critical for supporting fish and macroinvertebrate populations (Milner et al., 2003). Equally, fine sediment can impact negatively on macrophytes or diatoms by smothering, abrasion and scour (Clarke, 2002; Jones et al., 2014).

A range of mitigation measures to ameliorate agricultural diffuse pollution, including that resulting from excessive sediment loss from farms, have been identified by recent policy support projects funded by the Department for Environment, Food and Rural Affairs (Defra) (e.g. NewellPrice et al., 2011). These mitigation measures can be implemented through a number of means (McGonigle et al., 2012) including the basic regulatory expectations (Cross Compliance) of farmers to maintain land in good agricultural and environment condition (e.g. GAEC rule 1 embodied in the Soil Protection Review) as a mandatory requirement for receiving subsidy via the Single Payment Scheme, targeted programmes of advice such as the Catchment Sensitive Farming initiative (CSF) and agri-environment schemes (e.g. the existing Entry-Level scheme in England). However, demonstrating the effectiveness of these policy instruments has proved challenging, especially in the short term, given the complexities of sediment redistribution through the landscape with intermediate storage and remobilisation, highly changeable weather conditions 
from year to year and on account of the confounding influence of sediment contributions from alternative sources which may not be targeted by abatement strategies. In addition, disentangling the impact of specific policy instruments or mitigation measures present in the agricultural landscape on sediment loss from farms remains a major challenge using empirical methods.

Despite the evidence base for the detrimental environmental impacts of excessive sediment loss from agriculture, in the broader context of food security and the challenges of feeding a growing population, there is an expectation on farmers to increase food production. Consequently, there is renewed focus on sustainable intensification which embodies the balance between maximising agricultural productivity and minimising environmental burden including that on freshwaters (Foresight, 2011). Critical to this balance, is an improved understanding of the national scale cost-effectiveness of potential sediment mitigation strategies which might be delivered by a range of policy instruments. Accordingly, a collaborative scientific policy support project in the UK has been modelling the cost-effectiveness of on-farm sediment mitigation measures to provide insight into the costs to society of minimising the environmental pressures of modern agricultural production.

\section{METHOD}

The approach was founded on the use of the Excel-based decision support tool FARMSCOPER (FARM SCale Optimisation of Pollutant Emission Reductions) recently developed to help inform the management of diffuse agricultural pollution across England and Wales (Zhang et al., 2012; Gooday et al., 2014). FARMSCOPER is founded on a suite of well-established models which have all been used in national-scale predictions for policy support. These models simulate sediment, phosphorus, nitrate, ammonia, methane and nitrous oxide emissions to aquatic environments and the atmosphere. In the case of sediment, FARMSCOPER predictions use the Phosphorus and Sediment Yield CHaracterisation In Catchments (PSYCHIC) process-based model (Collins et al., 2007; Davison et al., 2008; Stromqvist et al., 2008; Collins et al., 2009a). For the construction of FARMSCOPER baseline predictions without prior implementation of abatement measures, the PSYCHIC model was applied using multiple iterations to the whole of England and Wales at $1-\mathrm{km}^{2}$ resolution. The results were area-weighted to produce output for six primary rainfall zones and three soil types (see rainfall and soil categories in Table 1). The soil types were chosen to reflect the likelihood of agricultural under-drainage: permeable free draining soils; impermeable soils where artificial drainage is required to make them suitable for arable cultivation; and, impermeable soils where artificial drainage is required to make them suitable for either arable or grassland agriculture. Soils for each $1-\mathrm{km}^{2}$ grid cell at national scale were identified using NATMAP1000 (National Soil Resources Institute, Cranfield University) and the corresponding HOST (Hydrology of Soil Types; Boorman et al., 1995) classes used to assign a FARMSCOPER soil category (Table 2). Agricultural management practice is simulated in FARMSCOPER using representative farm types derived from the Defra Robust Farm Type (RFT) classification scheme (Defra, 2010), which is widely adopted in existing farm surveys undertaken across England and Wales. Based on crop specific land areas and categorised livestock data collected in the 2010 June Agricultural Census, default values were identified to describe an 'average' model farm for each farm type for each soil and rainfall combination. Where enterprise specific data are available, FARMSCOPER allows for customisation of these farm types to support more tailored application of the tool. FARMSCOPER comprises a library of 105 mitigation methods, each of which is characterised in terms of its impacts on pollutant emissions and the costs or savings that implementation of the method would incur for farmers. Impacts of multiple mitigation methods are multiplicative, such that the effectiveness of multiple methods targeting the same aspects of pollutant loss will be less than the sum of their individual impacts. The costs of method implementation account for changes to the variable costs and gross margin of a crop or stock enterprise, changes to the fixed costs or overheads associated with labour and machinery and capital investment using a number of sources (e.g. Nix, 2009). Capital costs are typically amortised over 5 to 20 years, depending upon the expected lifetime of the corresponding 
investment and any associated loans. The simulations reported here are based on the latest mitigation measure costs for 2013. Costs exclude those to government for policy instrument administration and delivery or enforcement on the ground by agencies or officers.

Table 1 The relative frequency distribution of all possible FARMSCOPER rainfall and soil combinations across England and Wales; AAR is Annual average rainfall.

\begin{tabular}{llll}
\hline AAR & Soil categories: & & \\
$(1961-1990)$ & Free draining & Drained for arable & Drained for arable and grass \\
\hline $\mathrm{mm}$ & $\%$ & $\%$ & $\%$ \\
$<600$ & 2.5 & 4.5 & 2.4 \\
$600-700$ & 8.3 & 8.3 & 9.1 \\
$700-900$ & 13.1 & 6.8 & 10.1 \\
$900-1200$ & 10.5 & 2 & 3.9 \\
$1200-1500$ & 7.7 & 0.4 & 1.6 \\
$>1500$ & 7.8 & 0.3 & 0.9 \\
\hline
\end{tabular}

Table 2 The correspondence between HOST classes and FARMSCOPER soil categories.

\begin{tabular}{llll}
\hline HOST class & Soil group & HOST class & Soil group \\
\hline 1 & Free draining & 15 & Free draining \\
2 & Free draining & 16 & Free draining \\
3 & Free draining & 17 & Free draining \\
4 & Free draining & 18 & Drained for arable \\
5 & Free draining & 19 & Drained for arable \\
6 & Free draining & 20 & Drained for arable \\
7 & Free draining & 21 & Drained for arable \\
8 & Free draining & 22 & Drained for arable \\
9 & Drained for arable & 23 & Drained for both arable and grass \\
10 & Drained for arable & 24 & Drained for both arable and grass \\
11 & Free draining & 25 & Drained for both arable and grass \\
12 & Free draining & 26 & Free draining \\
13 & Free draining & 27 & Free draining \\
14 & Drained for arable & 28 & Free draining \\
\hline
\end{tabular}

In order to capture the spatial variation in the natural environment and farm types across England and Wales, the work to date has been running FARMSCOPER at the Environment Agency Water Management Catchment (WMC) scale (Fig. 1). The WMCs provide 100 reporting units although one was discounted due to its small area $\left(<1 \mathrm{~km}^{2}\right)$. Ongoing work is down scaling the WMC outputs to individual non-coastal water bodies ( 4500) used for reporting environmental status under the European Union Water Framework Directive (WFD; European Parliament, 2000). To create the typical model farms for each WMC, the livestock numbers and categories, land cover and cropping data derived for each RFT from the 2010 June Agricultural Census survey were paired up with corresponding rainfall and soil combinations. Default typical farm and field management practices for each farm type were used in conjunction with the structural information provided by the agricultural census returns. Among the 99 WMCs included in the simulations, 44\% have nine RFTs and 48\% have eight RFTs. Seven WMCs have fewer than eight RFTs. While the majority of WMCs are in England, eight WMCs are entirely inside Wales and five have water bodies in both countries. In total, $>5000$ typical model farms were created for England, $>700$ for Wales and nearly 400 for the border areas between England and Wales.

Existing or so-called prior implementation of mitigation measures is incorporated into FARMSCOPER to ensure that the technical potential for environmental change is not overestimated. Prior uptake represents a number of factors including the physiographic environment, farm type (i.e. applicability of a mitigation method) and the history of incentives via support or regulation. Estimates of prior implementation (for 2010) are expressed as a percentage of the applicable area or number of livestock or farm holdings. An additional distinction is made between measured uptake within and outside of Nitrate Vulnerable Zones (NVZs) since these have a regulatory Action Programme and although this is designed to target nitrate pollution, recent Defra 


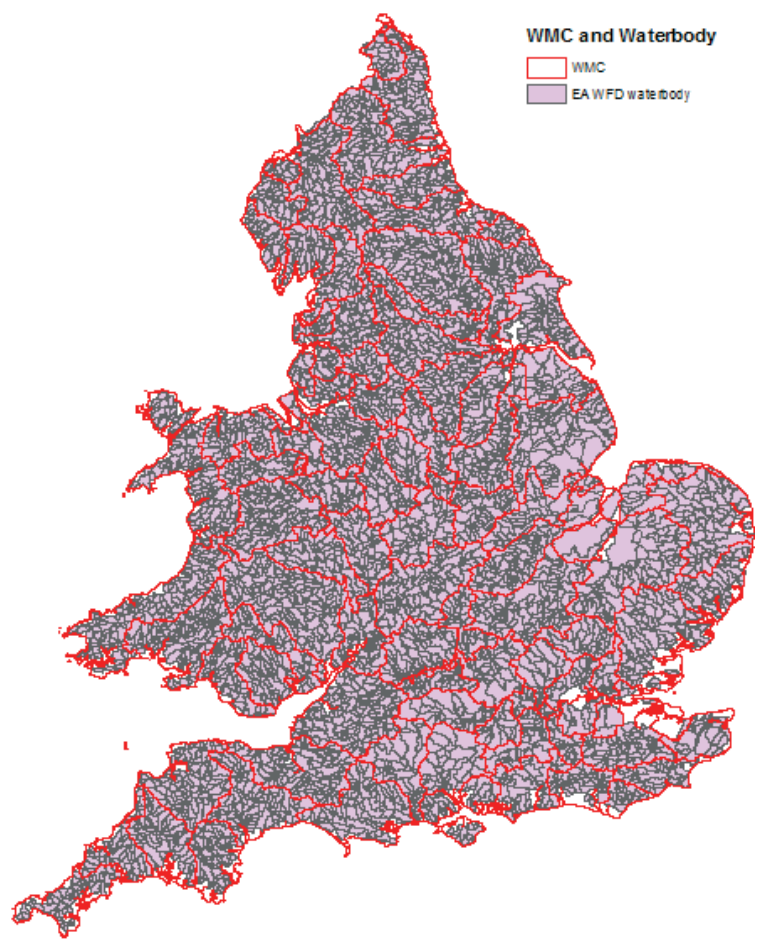

Fig. 1 Water Management Catchments (WMCs) and WFD water bodies across England and Wales.

Farm Practice Survey returns have collected some data which distinguish the uptake of some measures (e.g. management of grassland compaction) which can impact on sediment loss. The efficacy of individual mitigation methods in the FARMSCOPER library is based on a number of literature reviews (e.g. Newell-Price et al., 2011) and elicitation of expert judgement. To help account for gaps in the empirical evidence base for some mitigation options and the range in efficacy values reported for the same abatement measures by different studies (e.g. see review by Collins et al., 2009b), method efficacy is summarised in FARMSCOPER on an indicator scale to provide an uncertainty range for the potential pollutant reduction impacts (Table 3). The estimates of average efficacy are lower than the central values of the ranges to provide a conservative assessment of impact. Table 4 summarises the mitigation measures simulated in FARMSCOPER that have the potential to impact on sediment loss. When multiple methods are simulated, FARMSCOPER applies a multiplicative, rather than additive approach for efficacy, again, to avoid over-estimation of environmental impact. On the basis of this approach, the impact or efficacy of simulating the uptake of additional abatement measures decreases rapidly. FARMSCOPER takes explicit account of abatement method competition and thereby ensures that opposing management options (e.g. un-intensive versus intensive ditch management on arable or grassland; Table 4) cannot be simulated at the same time. Abatement method dependency is also included in the computational routines, meaning that an option dependent upon another can only be simulated in excess of its prior implementation if the measure upon which it depends is also implemented at a higher uptake rate.

Table 3 Average efficacy classes and corresponding uncertainty ranges.

\begin{tabular}{llll}
\hline Efficacy class & Average efficacy & Uncertainty range & Pollutant reduction \\
\hline A & - & - & None \\
B & 2 & $0-10$ & Very low \\
C & 10 & $2-25$ & Low \\
D & 25 & $10-50$ & Moderate \\
E & 50 & $25-80$ & High \\
F & 80 & $50-95$ & Very high \\
G & 100 & 100 & Total \\
\hline
\end{tabular}


Table 4 Mitigation measures relevant to sediment control simulated in the FARMSCOPER tool.

\begin{tabular}{|c|c|c|}
\hline Mitigation method ID & Description & Policy mechanism \\
\hline 1 & Establish cover crops in the autumn & Land management \\
\hline 2 & Early harvesting and establishment of crops in the autumn & Best practice / voluntary \\
\hline 3 & Cultivate land for crops in spring rather than autumn & Land management \\
\hline 4 & Adopt reduced cultivation systems & Best practice / voluntary \\
\hline 5 & Cultivate compacted tillage soils & Best practice / voluntary \\
\hline 6 & Cultivate and drill across the slope & Best practice / voluntary \\
\hline 7 & Leave autumn seed beds rough & Best practice / voluntary \\
\hline 8 & Manage over-winter tramlines & Incentive (capital) \\
\hline 9 & Establish in-field grass buffer strips & Incentive (land management) \\
\hline 10 & Establish riparian buffer strips & Incentive (land management) \\
\hline 11 & Loosen compacted soil layers in grassland fields & Best practice / voluntary \\
\hline 12 & Allow field drainage systems to deteriorate & Incentive (land management) \\
\hline 13 & Intensive ditch management on arable land & Incentive (land management) \\
\hline 14 & Intensive ditch management on grassland & Incentive (land management) \\
\hline 32 & Reduce the length of the grazing day / season & Incentive (land management) \\
\hline 34 & Reduce field stocking rates when soils are wet & Best practice / voluntary \\
\hline 35 & Move feeders at regular intervals & Best practice / voluntary \\
\hline 36 & Construct troughs with concrete base & Incentive (capital) \\
\hline 65 & Fence off rivers and streams from livestock & Incentive (capital) \\
\hline 66 & Construct bridges for livestock crossing rivers/streams & Incentive (capital) \\
\hline 67 & Re-site gateways away from high risk areas & Incentive (capital) \\
\hline 68 & Farm track management & Incentive (capital) \\
\hline 69 & Establish new hedges & Incentive (capital) \\
\hline 80 & Protection of infield trees & Incentive (land management) \\
\hline 82 & Management of infield ponds & Incentive (land management) \\
\hline 83 & Un-intensive ditch management on arable land & Incentive (land management) \\
\hline 84 & Un-intensive ditch management on grassland & Incentive (land management) \\
\hline 88 & Uncropped cultivated margins & Incentive (land use change) \\
\hline 89 & Skylark plots & Incentive (land management) \\
\hline 87 & Beetle banks & Incentive (land management) \\
\hline 85 & Management of field corners & Incentive (land management) \\
\hline 90 & Uncropped cultivated areas & Incentive (land management) \\
\hline 92 & Unharvested cereal headlands & Incentive (land management) \\
\hline 93 & Undersown spring cereals & Incentive (land management) \\
\hline 94 & Take field corners out of management & Incentive (land use change) \\
\hline 95 & Leave over-winter stubbles & Incentive (land management) \\
\hline 97 & $\begin{array}{l}\text { Use correctly-inflated low ground pressure tyres on } \\
\text { machinery }\end{array}$ & Best practice / voluntary \\
\hline 98 & Locate out-wintered livestock away from watercourses & Best practice / voluntary \\
\hline
\end{tabular}

\section{EXAMPLE RESULTS}

Table 5 presents a national-scale summary of the uncertainty ranges in the annual costs and corresponding efficacy of a policy scenario supporting the implementation of all mitigation measures, on the basis of individual Robust Farm Types present across England and Wales. The total numbers of mitigation measures implemented on each Robust Farm Type (Table 5) exceed the number of measures relevant to sediment control (Table 4) because FARMSCOPER simultaneously examines the potential reduction in additional pollutants of the aquatic environment (phosphorus, nitrate) and the atmosphere (ammonia, methane, nitrous oxide). Accordingly, the ranges in total costs in Table 5 reflect the simulation of all mitigation measures relevant to these multiple pollutants rather than just sediment alone. Summary statistics presented in Table 5 are relative to the existing uptake of abatement measures as driven by various current policy instruments including regulation and advice or support. These predictions are for average farms for each Robust Farm Type within each WMC and assume an uptake of $95 \%$ since $100 \%$ implementation was considered unrealistic. Table 5 shows that the predicted efficacy ranges for sediment do not differ significantly between those farms within or outside of NVZs since the statutory instrument for NVZs delivers an Action Programme which targets the control of nutrient rather than sediment pollution, although recent survey returns do suggest that the uptake of a limited number of measures relevant to sediment 
Table 5 Predicted national scale uncertainty ranges (relative to existing uptake of mitigation measures) in the annual costs and efficacy of a potential policy scenario supporting the implementation of all sediment mitigation methods, summarised by robust farm types present across England and Wales.

\begin{tabular}{|c|c|c|c|c|c|}
\hline Robust Farm Type & $\begin{array}{l}\text { Total no. of } \\
\text { mitigation measures } \\
\text { implemented }^{1}\end{array}$ & $\begin{array}{l}\text { Minimum total } \\
\text { cost } \\
(£)^{1}\end{array}$ & $\begin{array}{l}\text { Maximum total } \\
\text { cost } \\
(£)^{1}\end{array}$ & $\begin{array}{l}\text { Minimum } \\
\text { efficacy } \\
(\%)\end{array}$ & $\begin{array}{l}\text { Maximum } \\
\text { efficacy } \\
(\%)\end{array}$ \\
\hline $\begin{array}{l}\text { WITHIN NVZs } \\
\text { Cereals }\end{array}$ & $\begin{array}{l}\text { WITHIN NVZs } \\
62-89\end{array}$ & $-16,346$ & 75.609 & 1.3 & 79.7 \\
\hline General cropping & $48-90$ & $-27,234$ & 53,181 & 1.5 & 78.6 \\
\hline Horticulture & $44-90$ & $-146,402$ & 51,222 & 0.4 & \\
\hline Specialist pigs & $52-89$ & 884 & 82,549 & 0.5 & 79.6 \\
\hline Specialist poultry & $53-84$ & 320 & 29,209 & 0 & 78.7 \\
\hline Dairy & $45-89$ & 467 & 175,631 & 2.0 & 74.1 \\
\hline $\begin{array}{l}\text { Less favoured area } \\
\text { grazing livestock }\end{array}$ & $65-93$ & 4,456 & 60,480 & 2.1 & 51.8 \\
\hline $\begin{array}{l}\text { Lowland grazing } \\
\text { livestock }\end{array}$ & $62-91$ & 3,031 & 73,817 & 2.0 & 65.2 \\
\hline Mixed & $65-89$ & 221 & 99,760 & 0 & 78.7 \\
\hline OUTSIDE NVZs & OUTSIDE NVZs & & & & \\
\hline Cereals & $63-91$ & $-81,629$ & 76,860 & 1.3 & 79.7 \\
\hline General cropping & 49-92 & $-26,476$ & 54,877 & 1.5 & 78.6 \\
\hline Horticulture & $45-92$ & $-145,035$ & 52,164 & 0.4 & 79.7 \\
\hline Specialist pigs & $55-91$ & 774 & 74,816 & 0.5 & 79.6 \\
\hline Specialist poultry & $56-86$ & -971 & 29,090 & 0 & 78.7 \\
\hline Dairy & $46-91$ & 487 & 170,177 & 2.0 & 74.1 \\
\hline $\begin{array}{l}\text { Less favoured area } \\
\text { grazing livestock }\end{array}$ & $66-93$ & 4,287 & 59,503 & 2.1 & 51.8 \\
\hline $\begin{array}{l}\text { Lowland grazing } \\
\text { livestock }\end{array}$ & $63-91$ & 2,992 & 72,943 & 2.0 & 65.2 \\
\hline Mixed & $68-91$ & -226 & 100,932 & 0 & 78.7 \\
\hline
\end{tabular}

${ }^{1}$ The total number of mitigation measures and estimated annual costs reflect the implementation of additional abatement measures (i.e. in excess of those listed in Table 4) relevant to the control of phosphorus, nitrate and gaseous emissions

control does vary on the basis of whether farm businesses are within or outside of designated NVZs. Contrasts in the predicted uncertainty ranges for annual costs and effectiveness within or outside of NVZs are greater for other pollutants such nitrate or phosphorus. The uncertainty ranges in the predicted efficacy of the potential policy scenario by Robust Farm Type are significant, reflecting the spatial heterogeneity of abatement method effectiveness in the context of pollutant losses driven by the rainfall gradient across England and Wales (Table 1) and low to high risk soils supporting the same farm systems. In addition, variations in the predicted uncertainty ranges associated with the total annual efficacy and costs of the policy scenario reflect, in part, the applicability of individual abatement measures to the different Robust Farm Types (see numbers of measures implemented in Table 5). As a result, both the dairy and mixed farm types have particularly high maximum predicted annual costs given that the presence of a greater range of potential sources, such as grass and arable areas (e.g. fodder cropping on dairy farms and cereals on mixed farms) or farm steadings and manure/slurry stores on these farm systems, means that more mitigation measures are applicable. A number of measures applicable to arable land including 'establish cover crops in the autumn', 'early harvesting and establishment of crops in the autumn' and 'cultivated land for crops in spring rather than autumn' are relatively expensive, again increasing the maximum predicted costs for those farm system types where such methods are applicable. It is likely that some of the more expensive mitigation methods for cultivation systems will continue to be unpopular with the farming industry. The substantial cost savings in Table 5 (minimum cost predictions) for some farm system types reflect the positive impacts on mitigation costs associated with improved manure and fertiliser management options, rather than sediment control methods. Table 5 suggests that the maximum technical efficacy of sediment abatement for individual Robust Farm Types could be $\sim 80 \%$ and it is likely that reductions in sediment loss of this magnitude will be required in some areas to support healthier aquatic ecology. 


\section{CONCLUDING REMARKS}

Ongoing work as part of a policy support science project is assessing the national-scale costs and efficacy of different policy scenarios aimed to improve the protection of the freshwater aquatic environment across England and Wales from a number of pollutants including sediment. The results presented above suggest that significant reductions in current sediment loss from different farm system types are technically feasible although the associated uncertainty ranges are substantial. As an example, the modelled policy scenario is complex, with up to 93 measures, and is most likely impractical for delivery on the ground. The next phases of the work will merge the modelled outputs from FARMSCOPER with information on the spatial coverage of each farm type within the WMCs or WFD water bodies provided by the agricultural census returns for 2010 to estimate the weighted efficacy of sediment reduction for different spatial units used for environmental auditing and reporting. These latter outputs will be used within a wider modelling framework to assess the potential for different policy scenarios to close the pollutant gap between present day losses from the agricultural sector and those required to meet environmental targets. The latter work will correct the efficacy of on-farm mitigation measures and potential policy scenarios on the basis of source apportionment for the contributions from additional sectors such as urban areas and point source discharges (cf. Collins et al., 2014).

Acknowledgements The authors gratefully acknowledge the funding provided by the Department for Environment, Food and Rural Affairs (Defra project WQ0223; Developing a field tool kit for ecological targeting of agricultural diffuse pollution mitigation measures).

\section{REFERENCES}

Ballantine, D.J., et al. (2009) The content and storage of phosphorus in fine-grained channel bed sediment in contrasting lowland agricultural catchments in the UK. Geoderma 151, 141-149.

Boorman, D., Hollis, J. \& Lilly, A. (1995) Hydrology of soil types: a hydrologically-based classification of the soils of the United Kingdom. Institute of Hydrology Report No. 126, Wallingford, Oxfordshire, 134pp.

Collins, A.L., et al. (2007) Appraisal of phosphorus and sediment transfer in three pilot areas identified for the Catchment Sensitive Farming initiative in England: application of the prototype PSYCHIC model. Soil Use and Management 23, 117-132.

Collins, A.L., et al. (2009a) The potential impact of projected change in farming by 2015 on the importance of the agricultural sector as a sediment source in England and Wales. Catena 79, 243-250.

Collins, A.L., et al. (2009b) Mitigating diffuse water pollution from agriculture: riparian buffer strip performance with width. CAB Reviews: Perspectives in Agriculture, Veterinary Science, Nutrition and Natural Resources 4(39), 1-15.

Collins, A.L., et al. (2011) Sediment targets for informing river catchment management: international experience and prospects. Hydrological Processes 25, 2112-2129.

Collins, A.L., Stutter, M. \& Kronvang, B. (2014) Mitigating diffuse pollution from agriculture: international approaches and experience. Science of the Total Environment 468-469, 1173-1177.

Clarke, S.J. (2002) Vegetation growth in rivers: influences upon sediment and nutrient dynamics. Progress in Physical Geography 26, 159-172.

Davison, P., et al. (2008) PSYCHIC - A process based model of phosphorus and sediment mobilisation and delivery within agricultural catchments. Part 1: Model description and parameterisation. Journal of Hydrology 350, $290-302$.

Defra. (2010) Definitions of Terms used in Farm Business Management. 3rd ed. 48 pp.

European Parliament (2000) Directive 2000/60/EC of the European Parliament and of the Council of 23 October 2000 on establishing a framework for community action in the field of water policy. Official Journal of the European Union, L327: 1-72.

Foresight. (2011) The future of food and farming: final project report. Government Office for Science, London.

Gooday, R.D., et al. (2014) Modelling the cost-effectiveness of mitigation methods for multiple pollutants at farm scale. Science of the Total Environment 468-469, 1198-1209.

Horowitz, A.J., et al. (1995) Effect of mining and related activities on the sediment trace element geochemistry of Lake Coeur d'Alene, Idaho, USA. Part II: subsurface sediments. Hydrological Processes 9, 35-54.

Jones, J.I., et al. (2014) Interactions between diatoms and fine sediment. Hydrological Processes 28, $1226-1237$.

Kay, D., et al. (2005) Catchment microbial dynamics: the emergence of a research agenda. Progress in Physical Geography 31, 1-18.

Kemp, P., et al. (2011) The impacts of fine sediment on riverine fish. Hydrological Processes 25, 1800-1821.

McGonigle, D.F., et al. (2012) Towards a more strategic approach to research to support catchment-based policy approaches to mitigate agricultural water pollution: a UK case-study. Environmental Science and Policy 24, 4-14.

Milner, N.J., et al. (2003) The natural control of salmon and trout populations in streams. Fisheries Research 62, 111-125.

Newell-Price, J.P., et al. (2011) Mitigation methods - User Guide. Inventory of mitigation methods and guide to their effects on diffuse water pollution, greenhouse gas emissions and ammonia emissions from agriculture. Prepared as part of Defra project WQ0106.

Nix J. (2009) Farm Management Pocket Book. $36^{\text {th }}$ ed. Imperial College, London, 268 pp.

Stromqvist, J., et al. (2008) PSYCHIC - a process-based model of phosphorus and sediment transfers within agricultural catchments. Part 2. A preliminary evaluation. Journal of Hydrology 350, 303-316.

Warren, N., et al. (2003) Pesticides and other micro-organic contaminants in freshwater sedimentary environments - a review. Applied Geochemistry 18, 159-194.

Zhang, Y., Collins, A.L. \& Gooday, R.D. (2012) Application of the FARMSCOPER tool for assessing agricultural diffuse pollution mitigation methods across the Hampshire Avon Demonstration Test Catchment, UK. Environmental Science and Policy 24, 120-131. 